\title{
Physiology of the mixotrophic dinoflagellate Fragilidium subglobosum. II. Effects of time scale and prey concentration on photosynthetic performance
}

\author{
Per J. Hansen ${ }^{1, *}$, Alf Skovgaard ${ }^{1}$, Ronnie N. Glud ${ }^{1}$, Diane K. Stoecker ${ }^{2}$ \\ ${ }^{1}$ Marine Biological Laboratory, University of Copenhagen, Strandpromenaden 5, 3000 Helsingør, Denmark \\ ${ }^{2}$ University of Maryland Center for Environmental Science, Horn Point Laboratory, PO Box 775, Cambridge, \\ Maryland 21613, USA
}

\begin{abstract}
Photosynthetic performance and cellular chlorophyll a (chl a) content were studied in the mixotrophic dinoflagellate Fragilidium subglobosum during transition from phototrophic to mixotrophic growth and back again. Experiments were conducted at an irradiance of $50 \mu \mathrm{E} \mathrm{m} \mathrm{m}^{-2} \mathrm{~s}^{-1}$ and, for mixotrophic growth, in the presence of Ceratium tripos or C. lineatum. After 4 to $8 \mathrm{~d}$ in mixotrophic culture, cells of $F$. subglobosum had reduced both their cellular chl a content to $47 \%$ and the photosynthetic performance to $\sim 42 \%$ of that found in phototrophic cultures. Net production of $\mathrm{chl} a$ in phototrophic and mixotrophic F. subglobosum cells was the same, indicating that feeding in F. subglobosum does not repress chl a production in mixotrophic cells. Thus, the reduction in cellular chl a content observed in mixotrophic $F$. subglobosum cells was caused by an increase in growth rate due to feeding. In cultures close to steady state, the photosynthetic performance at low prey concentrations was similar to values obtained by monocultures of $F$. subglobosum. However, above a certain prey concentration, photosynthetic performance decreased exponentially with an increase in prey concentration. The application of the traditional ${ }^{14} \mathrm{C}$ labeled $\mathrm{HCO}_{3}{ }^{-}$technique to measure photosynthesis in mixotrophically grown cells underestimated rates by 5 to $12 \%$, probably due to fixation of $\mathrm{CO}_{2}$ produced from respiration of ingested carbon. In phototrophic and mixotrophic $F$. subglobosum cells 46 and $28 \%$ of the assimilated carbon is used for respiration, respectively. This indicates that $F$. subglobosum needs more energy to synthesize, maintain and run the photosynthetic apparatus than the heterotrophic apparatus involved in prey capture, digestion and assimilation.
\end{abstract}

KEY WORDS: Mixotrophy · Primary production · Dinoflagellate $\cdot$ Growth $\cdot$ Chlorophyll a $\cdot$ Fragilidium subglobosum

Resale or republication not permitted without written consent of the publisher

\section{INTRODUCTION}

It is now well established that mixotrophy is common among photosynthetic (plastidic) flagellate groups in both freshwater and marine environments. A large number of plastidic species belonging to the chrysophytes, dinoflagellates, and prymnesiophytes are now regarded as having the potential for mixotrophy (e.g. Porter 1988, Green 1990, Hansen 1998). Among the dinoflagellates about 40 species are now considered as

*E-mail: mblpjh@inet.uni2.dk mixotrophs, most of which have their own chloroplasts (see Hansen 1998, Stoecker 1999). Even species implicated in red tides such as Prorocentrum minimum, Ceratium spp., Gymnodinium galatheanum, G. sanguineum and Heterocapsa triquetra are now known to be capable of feeding (Bockstahler \& Coats 1993, Li et al. 1997, Stoecker et al. 1997, Legrand et al. 1998, Li et al. 1999).

It has become clear that mixotrophic phytoflagellates may vary widely in their photosynthetic and ingestion capabilities. Thus phytoflagellates cover a spectrum of nutritional strategies from almost exclusively hetero- 
trophic to strictly autotrophic (e.g. Jones 1994). However, the regulation of the photosynthetic apparatus as a function of food availability has previously only been studied in a few mixotrophic phytoflagellates.

At the heterotrophic end of the nutritional spectrum, we have species such as the chrysophytes Poterioochromonas malhamensis and Ochromonas spp. They are able to reduce their cellular chlorophyll $a(\mathrm{chl} a)$ content considerably. In P. malhamensis a reduction of the cellular chl a content by as much as 93 to $99 \%$ when exposed to food in excess has been reported (Sanders et al. 1990). At the autotrophic end of the spectrum, we have species like the prymnesiophyte Chrysochromulina brevifilum. No reduction of the cellular chl a content could be detected in this species when fed another alga in a mixotrophic culture (Jones et al. 1995). The dinoflagellate Fragilidium subglobosum falls between these 2 extremes (Skovgaard 1996, Hansen \& Nielsen 1997). This species can grow phototrophically in light on inorganic nutrients and heterotrophically in the dark when fed another dinoflagellate belonging to the genus Ceratium. However, the highest growth rates were obtained when it was supplied with both light and food. F. subglobosum does reduce its cellular chl a content when fed, at least at irradiances below $100 \mu \mathrm{E} \mathrm{m}^{-2} \mathrm{~s}^{-1}$ (Skovgaard 1996). A reduction of the cellular chl a content in F. subglobosum by as much as $67 \%$ was found at low irradiances (Skovgaard et al. 2000, in this issue).

The present paper is the second of 2 papers dealing with the interaction between photosynthesis and phagotrophy in the dinoflagellate Fragilidium subglobosum. In the first paper, Skovgaard et al. (2000) describe the effect of phagotrophy on photosynthesis of $F$. subglobosum at different irradiances. The aim of the present paper was to study the regulation of photosynthesis and metabolism in the dinoflagellate F. subglobosum. We did this by investigating: (1) cellular chl $a$ content, cell volume, growth and photosynthetic performance of $F$. subglobosum in transition from phototrophic growth to mixotrophic growth and back again, (2) short-term effects of prey ingestion on cellular chl a content and photosynthetic performance, (3) effects of prey density on photosynthetic performance, and finally (4) respiration rate in phototrophic and mixotrophic cells of $F$. subglobosum.

\section{MATERIALS AND METHODS}

Culturing of organisms. The dinoflagellates Fragilidium subglobosum, Ceratium lineatum and C. tripos were isolated from the Kattegat, Denmark (Skovgaard 1996, Hansen \& Nielsen 1997). All organisms were grown as non-axenic cultures in B-medium (Hansen
1989) based on seawater (30 psu) at $15 \pm 1^{\circ} \mathrm{C}$ following a light:dark cycle of 16:8 h. Illumination was provided by cool white fluorescent lamps at an irradiances of ca $20 \mu \mathrm{E} \mathrm{m} \mathrm{m}^{-2} \mathrm{~s}^{-1}$.

Experimental conditions. Experiments were carried out in 250 or $750 \mathrm{ml}$ polystyrene bottles allowing light from only 1 direction at a temperature of $15 \pm 1^{\circ} \mathrm{C}$, unless otherwise stated. The irradiances was $50 \mu \mathrm{E} \mathrm{m}^{-2}$ $\mathrm{s}^{-1}$ in all experiments, because previous experiments have shown that this irradiances lies about mid-way between the compensation point and saturation and because feeding has a large effect on the photosynthetic rate of Fragilidium subglobosum at around this irradiance (Skovgaard et al. 2000). Irradiance was measured using a Li-Cor LI-1000 radiation sensor equipped with a Li-Cor LI-192SA probe. The experimental bottles were mounted vertically on a rotating wheel (1 rpm) in order to keep the algae in suspension. All algal cultures were in an exponential growth phase prior to initiation of the experiments listed below.

Effect of food uptake on photosynthesis, growth rate, chl $\boldsymbol{a}$ and cell volume. Experiments were carried out to study the effect of food uptake on photosynthetic performance, chl a cell volume and growth rate of Fragilidium subglobosum during the transition from phototrophy to mixotrophy using both a large (Ceratium tripos) and a small (C. lineatum) prey item. Experiments were initiated by mixing exponentially growing cultures of $F$. subglobosum and $C$. lineatum or C. tripos. The initial density of $F$. subglobosum was 5 cells ml ${ }^{-1}$, while the prey densities of $C$. lineatum and C. tripos were 200 and 50 cells $\mathrm{ml}^{-1}$, respectively. These prey concentrations were chosen in order to avoid an initial limitation of food for F. subglobosum, but so that they would still deplete the prey within about 1 wk. Subsampling ( $10 \%$ of the experimental volume) was carried out within intervals of 2 to $3 \mathrm{~d}$ for between 9 and $21 \mathrm{~d}$ and fresh B-medium was added to the experimental bottles to replace the sampled volume. Photosynthetic performance, chl a, cell volume and growth rates were measured simultaneously in $F$. subglobosum cells from a monoculture for comparison. Each experiment was carried out in 4 replicates.

By use of the single-cell ${ }^{14} \mathrm{C}$ technique, photosynthesis was measured in Fragilidium subglobosum by transferring 20 to 40 cells to a glass vial $(20 \mathrm{ml})$ containing $2 \mathrm{ml} \mathrm{B}$-medium. Cells were incubated for $3 \mathrm{~h}$ at an irradiances of $50 \mu \mathrm{E} \mathrm{m}^{-2} \mathrm{~s}^{-1}$ (see Skovgaard et al. 2000).

Cellular content of chl a in Fragilidium subglobosum and Ceratium tripos was measured using a fluorometer. A total of 150 cells were picked using a micropipette and extracted in $4 \mathrm{ml}$ of $96 \%$ ethanol. For calibration of the fluorometer with a spectrophotometer, a dense suspension of $F$. subglobosum or $C$. tripos cells 
was extracted, and a dilution series was run on the fluorometer.

For enumeration of cells and determination of cell volume a part of the subsamples were fixed in Lugol's solution (1\% final concentration). Instantaneous growth rates of Fragilidium subglobosum were determined with intervals of 2 to $3 \mathrm{~d}$ as: $\mu=\ln \left(N_{1} / N_{0}\right) t^{-1}$, where $N_{0}$ and $N_{1}$ refer to the cell concentrations at Days $t_{0}$ and $t_{1}$, respectively. The dimensions of $F$. subglobosum were determined by microscopic examination of Lugol's fixed cells ( $\mathrm{n}=20$ to 80 cells) and cell volume was calculated assuming a sphere.

Effect of prey concentration on the photosynthetic performance. In order to study the effect of prey concentration on photosynthetic performance, Fragilidium subglobosum was fed either Ceratium tripos or C. lineatum at concentrations ranging from 0 to 60 cells ml $^{-1}$ and 0 to 600 cells ml $^{-1}$, respectively. For each prey concentration, 4 bottles were incubated. The experiments were initiated by mixing cultures of $F$. subglobosum with $C$. tripos or C. lineatum. Because C. lineatum grows at a much higher rate than $C$. tripos, initial concentrations of $F$. subglobosum were higher in experiments using C. lineatum ( 2 to 5 cells $\mathrm{ml}^{-1}$ ) as prey compared to those in which the prey was C. tripos (0.5 to 1 cells $\mathrm{ml}^{-1}$ ). In order to achieve close to steady state values of photosynthetic performance, 2 requirements have to be met: (1) cells must be adapted to mixorophy, and (2) the prey concentration has to be fairly constant some days prior to measurements of photosynthetic performance. In order to meet the first requirement, mixed cultures of F. subglobosum and Ceratium spp. were incubated for at least $7 \mathrm{~d}$ prior to the measurements of photosynthetic performance. The results from the transition experiments demonstrated that an incubation period of this length is needed in order for $F$. subglobosum to adapt its photosynthetic apparatus to mixotrophic conditions. The second requirement was met by ensuring that the prey concentration changed less than $15 \%$ over 3 consecutive days prior to the measurements of the photosynthetic performance of $F$. subglobosum cells.

Short-term response in chl $a$ and photosynthetic performance in single cells after the ingestion of a large prey. The immediate effect on the photosynthetic performance of ingestion of a large prey item by Fragilidium subglobosum cells was studied. A culture of $F$. subglobosum was mixed with a culture of Ceratium tripos. Cells of F. subglobosum were allowed to feed for $30 \mathrm{~min}$, after which photosynthetic rates of cells that had just ingested a single prey item were measured by the single-cell ${ }^{14} \mathrm{C}$ technique (4 replicates of 20 to 40 cells). In practice this was done by picking only cells which had an ingested prey cell inside a food vacuole. A similar procedure was repeated with cells that after having been allowed to feed for $30 \mathrm{~min}$ were isolated for 3, 6, 9 and $24 \mathrm{~h}$ prior to measurements of photosynthesis.

Similarly, the immediate effect of ingestion of a large prey item on chl a content of Fragilidium subglobosum cells previously grown in monoculture was studied. After being allowed to feed for $30 \mathrm{~min}$, cells of F. subglobosum that had fed were transferred to scintillation vials containing fresh medium. The cells were incubated in the vials for $4.5,7.5,10.5$ and $24 \mathrm{~h}$ prior to chlorophyll extraction.

Respiration experiments. The $\mathrm{O}_{2}$ consumption rate was measured in phototrophic and mixotrophic cultured Fragilidium subglobosum that had been fed Ceratium tripos. In each case 400 individual cells were picked by micropipette, washed in $0.2 \mu \mathrm{m}$ filtered Bmedium, transferred to handmade glass ampoules of approximately $700 \mu \mathrm{l}$ (500 to $1000 \mu \mathrm{l}$ ) and incubated in the dark. The exact volume of each ampoule was determined from the weight difference between empty and water-filled ampoules. The incubation was initiated by sealing the opening with silicone grease, and the $\mathrm{O}_{2}$ concentration within each ampoule was continuously recorded by an $\mathrm{O}_{2}$ microelectrode. The tip diameter of the sensors was 5 to $20 \mu \mathrm{m}_{i}$ the stirring effect was $<1 \%$ and the $90 \%$ response time $<1 \mathrm{~s}$ (Revsbech 1989, Glud et al. in press). The electrode was positioned by a micromanipulator and the sensor current was measured with a pico-amperemeter connected to a strip-chart recorder (Revsbech \& Jørgensen 1986). Prior to the incubations a 2-point calibration was performed by introducing the sensor into air-saturated and $\mathrm{O}_{2}$-free water, respectively.

The water phase of the ampoules was gently mixed by an enclosed magnet that received momentum from an externally rotating magnet. The $\mathrm{O}_{2}$ consumption rate was calculated from the initial linear decrease in $\mathrm{O}_{2}$ concentration (first $3 \mathrm{~h}$ ).

Cellular carbon. The cellular contents of carbon were measured for Ceratium tripos and for Fragilidium subglobosum which had been fed C. tripos at an irradiance of $50 \mu \mathrm{E} \mathrm{m} \mathrm{m}^{-2} \mathrm{~s}^{-1}$. For a detailed description see Skovgaard et al. (2000).

\section{RESULTS}

\section{Shifts in photosynthetic performance, chl $a$, growth rate and cell volume of cultures of Fragilidium subglobosum}

The photosynthetic performance of Fragilidium subglobosum, grown in monocultures, was on average $129 \mathrm{pg} \mathrm{C}$ cell $^{-1} \mathrm{~h}^{-1}$ at an irradiance of $50 \mu \mathrm{E} \mathrm{m} \mathrm{m}^{-2} \mathrm{~s}^{-1}$ (Figs. $1 \& 2$, Table 1). When subjected to dense sus- 
Table 1. Average rates of photosynthetic performance, growth rates and chl a content of phototrophic and mixotrophic Fragilidium subglobosum cells derived from the data set shown in Figs. 1 to 4 . Numbers refer to treatment means $\pm 1 \mathrm{SE}$, $\mathrm{n}=$ number of replicates

\begin{tabular}{|c|c|c|c|}
\hline & 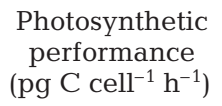 & $\begin{array}{c}\text { Chl } a \\
\left(\text { pg chl } a \text { cell }{ }^{-1}\right)\end{array}$ & $\begin{array}{l}\text { Growth rate } \\
\qquad\left(\mathrm{d}^{-1}\right)\end{array}$ \\
\hline $\begin{array}{l}\text { Phototrophic } \\
\text { F. subglobosum }\end{array}$ & $129 \pm 7(\mathrm{n}=20)$ & $167 \pm 5(\mathrm{n}=24)$ & $0.125 \pm 0.017(n=33)$ \\
\hline $\begin{array}{l}\text { Mixotrophic } \\
\text { F. subglobosum }\end{array}$ & $54 \pm 4(\mathrm{n}=20)$ & $78 \pm 4(\mathrm{n}=24)$ & $0.41 \pm 0.02(\mathrm{n}=38)$ \\
\hline
\end{tabular}

obtained in monospecific cultures. The reduction in photosynthetic performance was achieved within 4 to $8 \mathrm{~d}$ after the addition of food. We also examined the changes in photosynthetic performance when mixotrophic cultures of F. subglobosum had depleted their food source (Fig. 2). The photosynthetic rate reached a value that was similar to that obtained by monospecific cultures of F. subglobosum approximately $7 \mathrm{~d}$ after the prey was depleted.

pensions of either Ceratium lineatum or C. tripos, the photosynthetic performance of F. subglobosum decreased to $54 \mathrm{pg} \mathrm{C}$ cell $^{-1} \mathrm{~h}^{-1}$, which is $42 \%$ of that
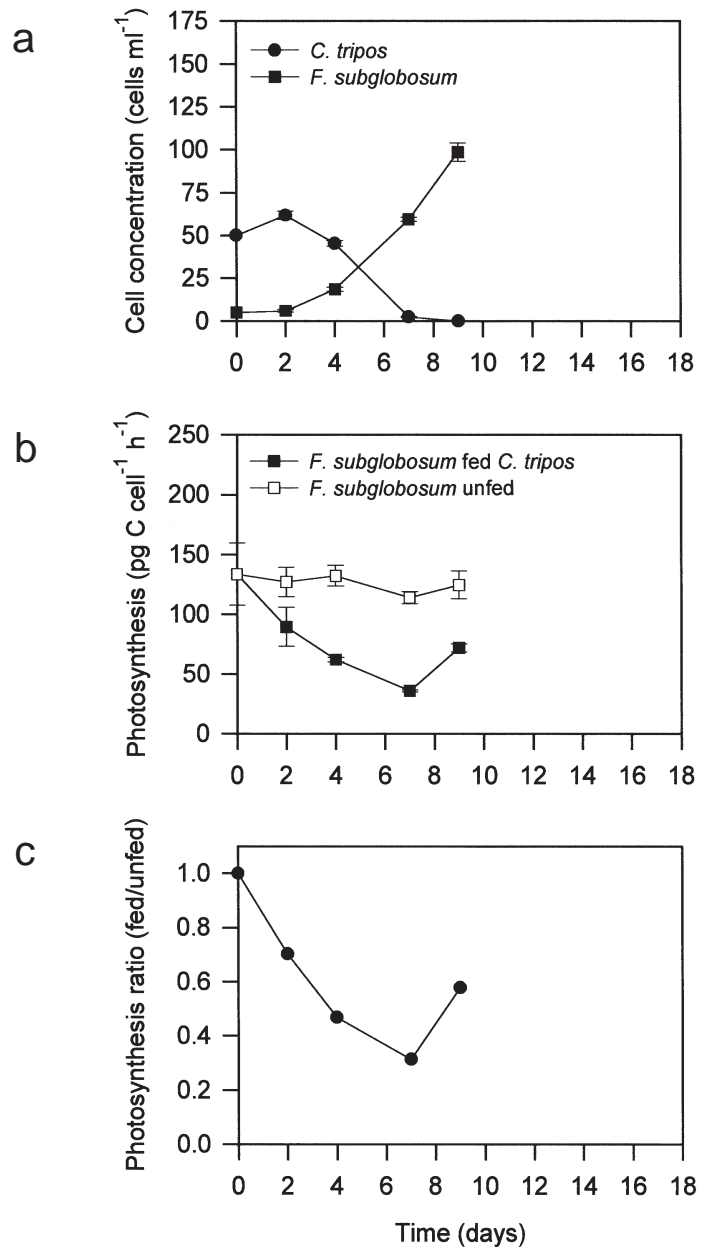

Fig. 1. Photosynthetic performance at $50 \mu \mathrm{E} \mathrm{m} \mathrm{m}^{-2} \mathrm{~s}^{-1}$ in a transition experiment in which cultures of Fragilidium subglobosum and Ceratium tripos were mixed at time 0. (a) Concentration of cells as a function of time. The prey is completely depleted at Day 9. (b) Photosynthetic rate $\left(\mathrm{pg} \mathrm{C} \mathrm{cell}^{-1} \mathrm{~h}^{-1}\right.$ ) of fed and unfed cells. (c) Ratio of photosynthesis between fed cells and unfed cells. Data points represent treatment means $\pm 1 \mathrm{SE}$
The average chl a content of Fragilidium subglobosum cells grown in monoculture at an irradiance of $50 \mu \mathrm{E} \mathrm{m} \mathrm{m}^{-2} \mathrm{~s}^{-1}$ was $167 \mathrm{pg}$ chl a cell ${ }^{-1}$ (Figs. $3 \& 4$,

a

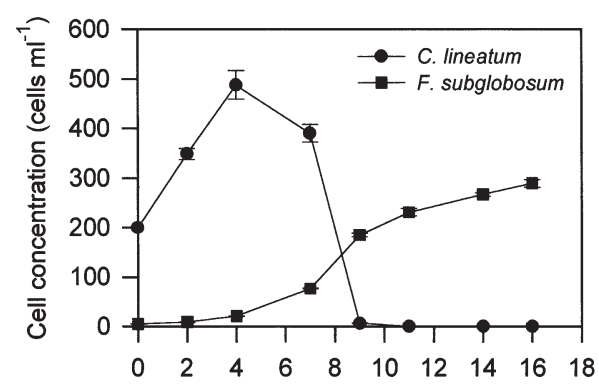

b

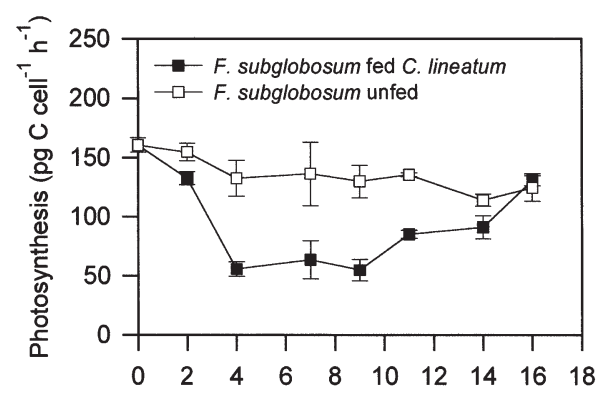

C

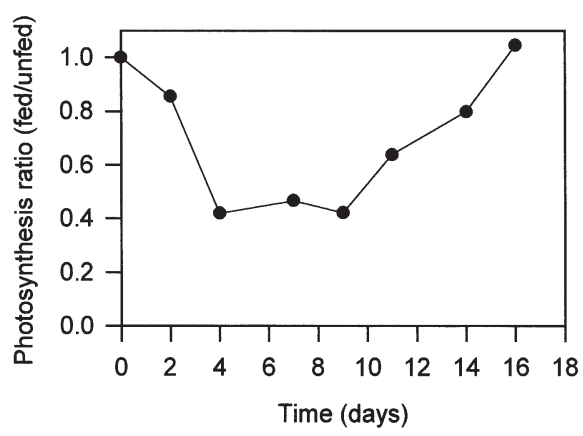

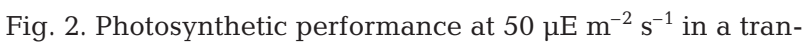
sition experiment in which cultures of Fragilidium subglobosum and Ceratium lineatum were mixed at time 0. (a) Concentration of cells as a function of time. The prey is completely depleted at Day 11. (b) Photosynthetic rate $\left(\mathrm{pg} \mathrm{C} \mathrm{cell}^{-1} \mathrm{~h}^{-1}\right)$ of fed and unfed cells. (c) Ratio of photosynthesis between fed cells and unfed cells. Data points represent treatment means $\pm 1 \mathrm{SE}$ 
Table 1). When subjected to dense suspensions of Ceratium lineatum and C. tripos, the chl a content decreased to an average of $78 \mathrm{pg} \mathrm{chl} a$ cell $^{-1}$, which is $47 \%$ of that found in monospecific cultures of F. subglobosum. This reduction was achieved 4 to $8 \mathrm{~d}$ after

a

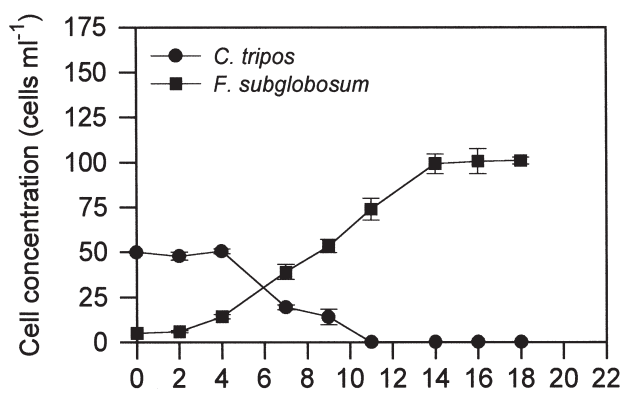

b

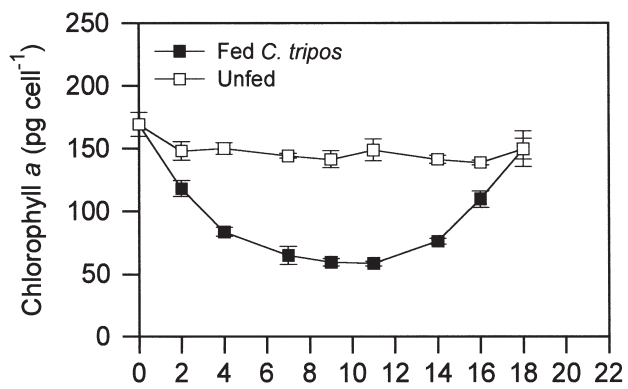

C

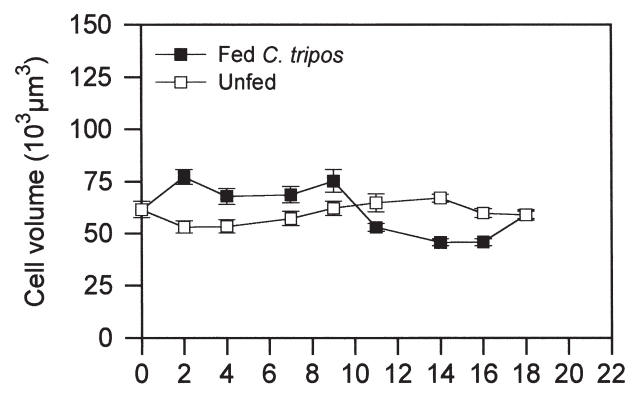

d

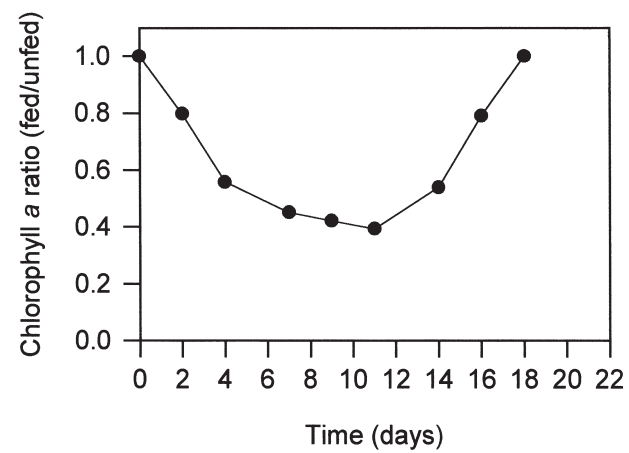

Fig. 3. Cellular content of chl $a$ and cell volume at $50 \mu \mathrm{E} \mathrm{m} \mathrm{m}^{-2}$ $\mathrm{s}^{-1}$ in a transition experiment in which cultures of Fragilidium subglobosum and Ceratium tripos were mixed at time 0 . (a) Concentration of cells as a function of time. The prey is completely depleted at Day 11. (b) Cell volume of F. subglobosum $\left(\mu^{3} \times 10^{3}\right)$ and cellular chl a content of $F$. subglobosum (pg cell ${ }^{-1}$ ) of fed and unfed cells. (d) Ratio of cellular content of chl a between fed cells and unfed cells. Data points represent treatment means $\pm 1 \mathrm{SE}$ the addition of prey. When a mixotrophic culture of F. subglobosum was depleted of food, the chl a cell content reached a value after ca $7 \mathrm{~d}$, which is similar to that in monospecific cultures of $F$. subglobosum at the same irradiance.

a

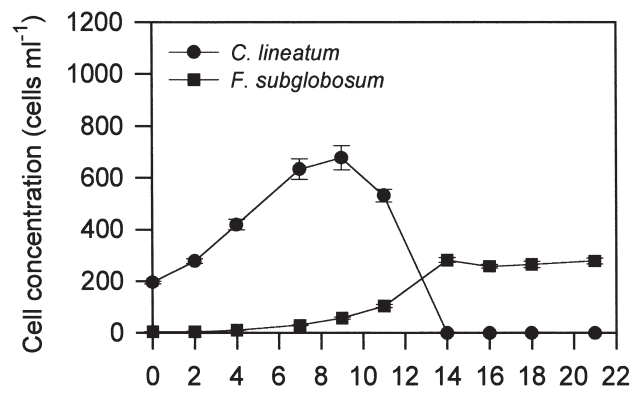

b

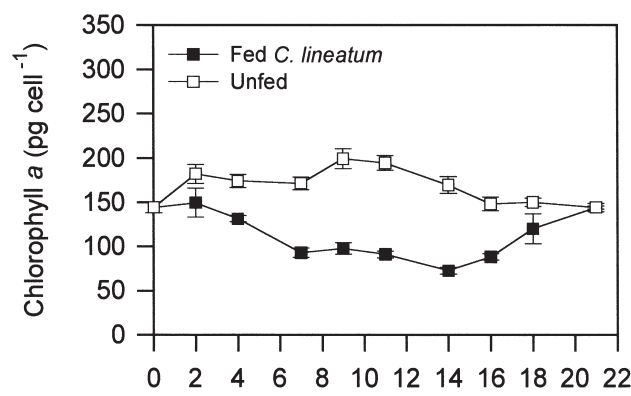

C

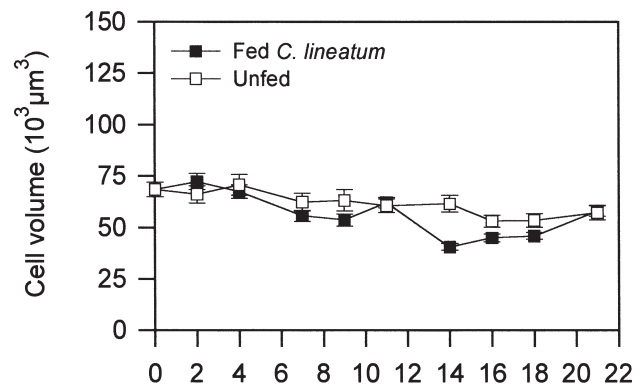

d

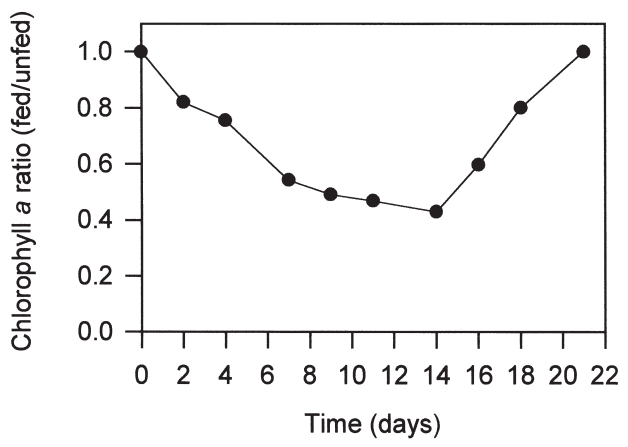

Fig. 4. Cellular content of chl $a$ and cell volume at $50 \mu \mathrm{E} \mathrm{m} \mathrm{m}^{-2}$ $\mathrm{s}^{-1}$ in a transition experiment in which cultures of Fragilidium subglobosum and Ceratium lineatum are mixed at start of the experiment. (a) Concentration of cells as a function of time. The prey is completely depleted at Day 14. (b) Cell volume $\left(\mu \mathrm{m}^{3} \times 10^{3}\right)$ and (c) cellular chl a content $\left(\mathrm{pg}\right.$ cell $\left.{ }^{-1}\right)$ of $F$. subglobosum of fed and unfed cells. (d) Ratio of chl a between fed cells and unfed cells. Data points represent treatment means $\pm 1 \mathrm{SE}$ 
Table 2. Cellular chl a and carbon content of Ceratium tripos in monoculture and carbon content of Fragilidium subglobosum in mixotrophic culture fed $C$. tripos at an illumination of $50 \mu \mathrm{E} \mathrm{m} \mathrm{m}^{-2} \mathrm{~s}^{-1}$. Numbers represent means $\pm 1 \mathrm{SE}, \mathrm{n}=$ number of replicates

\begin{tabular}{|lcc|}
\hline Species & C. tripos & $\begin{array}{c}\text { F. subglobosum } \\
\text { (fed C. tripos) }\end{array}$ \\
\hline $\begin{array}{l}\text { Carbon content } \\
\left(\mathrm{ng} \mathrm{C} \mathrm{cell}{ }^{-1}\right)\end{array}$ & $12.2 \pm 0.7(\mathrm{n}=4)$ & $9.37 \pm 0.48(\mathrm{n}=4)$ \\
$\begin{array}{l}\mathrm{Chl} a \\
(\mathrm{pg} \mathrm{cell}\end{array}$ & $111 \pm 3(\mathrm{n}=4)$ & $61.1 \pm 1.5$ \\
\hline
\end{tabular}

\section{Cell volume and carbon content}

The cell volume of Fragilidium subglobosum in monoculture was $\sim 60000 \mu^{3}$ (Figs. $3 \& 4$ ). In mixotrophic culture the volume of $F$. subglobosum depended on the size of the prey offered. When fed the smaller prey species Ceratium lineatum, the cell volume of $F$. subglobosum did not change, whereas when fed the larger species C. tripos, the cell volume increased to $\sim 75000 \mu^{3}$. As soon as mixotrophic cultures of F. subglobosum had depleted the food, their cell volume decreased to about $50000 \mu^{3}$. Thereafter it increased, and after about $7 \mathrm{~d}$ the cell volume was similar to that found in monocultures of F. subglobosum. The cellular carbon content of $C$. tripos and $F$. subglobosum, which had been fed C. tripos, was 12200 and 9370 pg C cell ${ }^{-1}$, respectively (Table 2).

\section{Growth}

Fragilidium subglobosum in phototrophic culture grew at an average rate of $0.13 \mathrm{~d}^{-1}$ at an irradiance of $50 \mu \mathrm{E} \mathrm{m} \mathrm{m}^{-2} \mathrm{~s}^{-1}$ (Table 1, Fig. 5). In the transition experiments, where F. subglobosum was fed either Ceratium lineatum or $C$. tripos, the growth rate of F. subglobosum increased to a maximum rate of $\sim 0.41 \mathrm{~d}^{-1}$ after $2 \mathrm{~d}$ of incubation (the growth rate at Day 4 on Fig. 5 refers to a growth calculated using cell numbers from Days 2 and 4). After the prey was depleted (or almost), the growth rate of $F$. subglobosum decreased to a level similar to or slightly lower than that obtained in phototrophic cultures.

\section{Photosynthesis in Fragilidium subglobosum as a function of food concentration}

At low prey concentrations the photosynthetic performance of Fragilidium subglobosum was about 105 to a

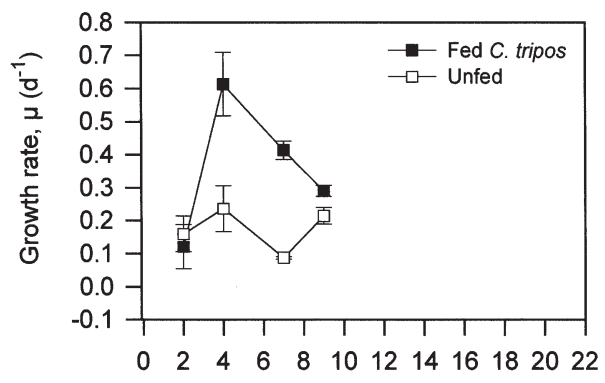

b

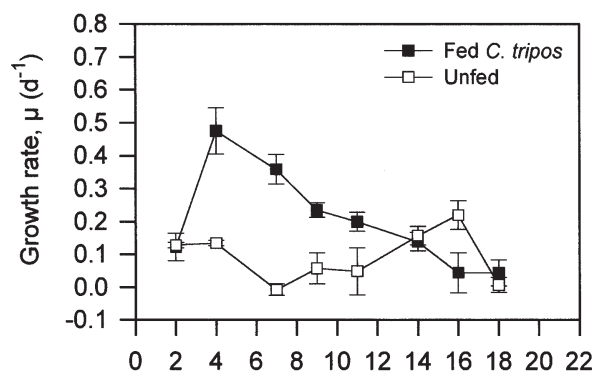

C

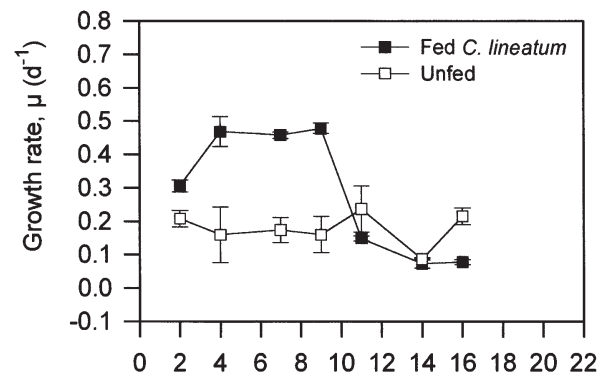

d

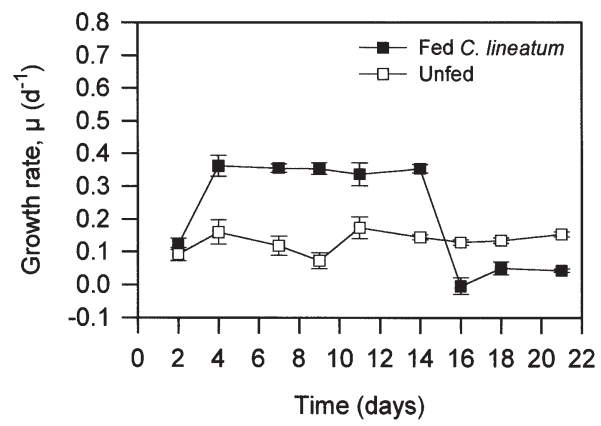

Fig. 5. Growth rate of phototrophic and mixotrophic cultures of Fragilidium subglobosum calculated from the transition experiments shown in Figs. 1 to $4 . x$-axis: the growth rate plotted at given day is calculated using the cell concentrations from this day and the previous sampling day. $(a, b, c, d)$ Growth data derived from the experiment shown in Figs. 1, 2, 3 \& 4, respectively

$130 \mathrm{pg} \mathrm{C} \mathrm{cell}^{-1} \mathrm{~h}^{-1}$, which is similar to values obtained by monocultures of $F$. subglobosum at the same irradiance (Fig. 6). However, above a certain prey concentration, photosynthetic performance decreased exponentially as a function of food concentration to reach a level of 40 to $60 \mathrm{pg} \mathrm{C}$ cell $^{-1} \mathrm{~h}^{-1}$ at prey concentrations above 3 to 5 Ceratium tripos or 150 to 300 C. lineatum cells $\mathrm{ml}^{-1}$. 
a

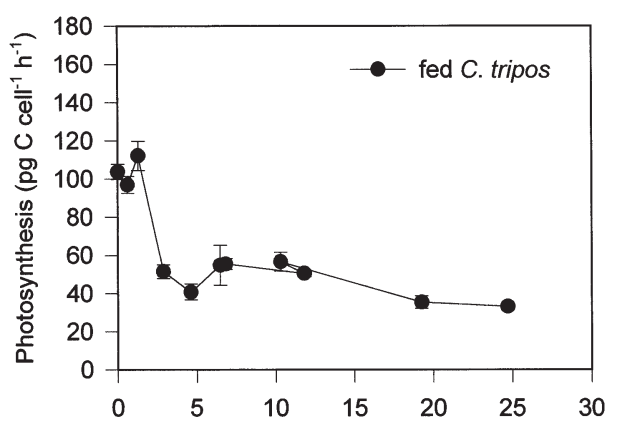

b

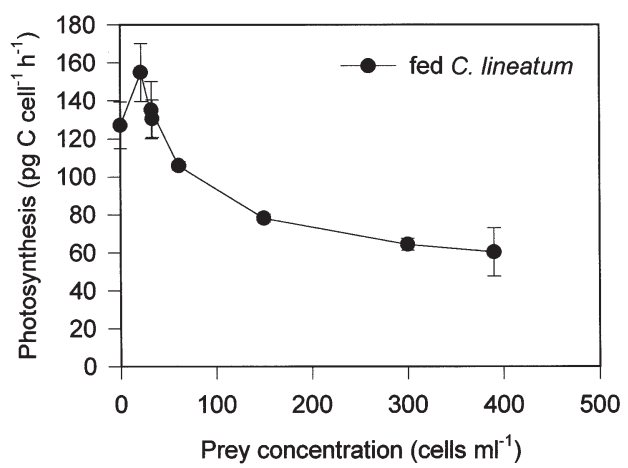

Fig. 6. Photosynthetic performance $\left(\mathrm{pg} \mathrm{C}\right.$ cell $\left.{ }^{-1} \mathrm{~h}^{-1}\right)$ in Fragilidium subglobosum as a function of prey concentration at an irradiance of $50 \mu \mathrm{E} \mathrm{m} \mathrm{m}^{-2} \mathrm{~s}^{-1}$. (a) Prey item Ceratium tripos.

(b) Prey item C. lineatum

Short-term responses of chl a content and photosynthetic performance after ingestion of a large prey

Immediately after the ingestion of a single large Ceratium tripos cell, the chl a content of a Fragilidium subglobosum cell increased by $70 \%$ (Fig. 7). The chl a content subsequently decreased as a function of time, and after $11 \mathrm{~h}$, the chl a content reached a level not significantly different from that found in cells that had not been fed. In contrast to the chl $a$ content, photosynthetic performance decreased for the first $8 \mathrm{~h}$ (Fig. 7). The largest decrease was found after 4 to $7 \mathrm{~h}$, when photosynthesis decreased to $\sim 60 \%$ of that found in unfed cells. Chl a-normalized photosynthesis $\left(P^{*}\right)$ decreased to $40 \%$ of that found in unfed cells.

\section{Respiration experiments}

Respiration rates were measured in Fragilidium subglobosum cells from monocultures and from mixotrophic cultures that had been fed Ceratium tripos (Table 3). The results of a typical experiment are shown in Fig. 8. The respiration rate of phototrophic cells was 70 pmol $\mathrm{O}_{2}$ cell $^{-1} \mathrm{~d}^{-1}$, while mixotrophic cells a

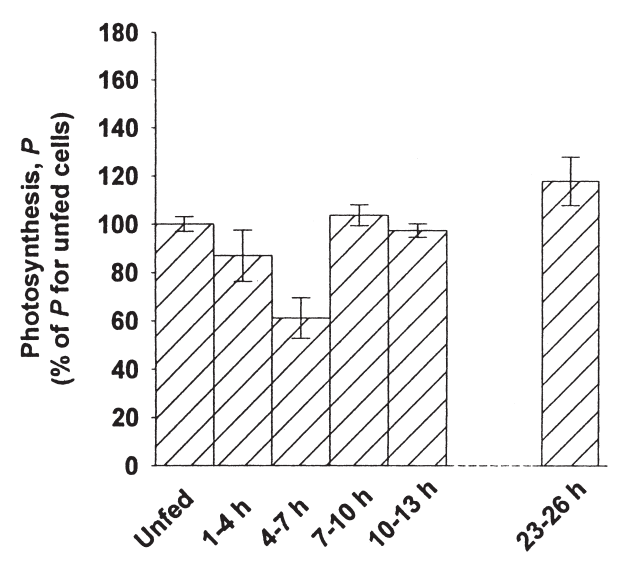

b
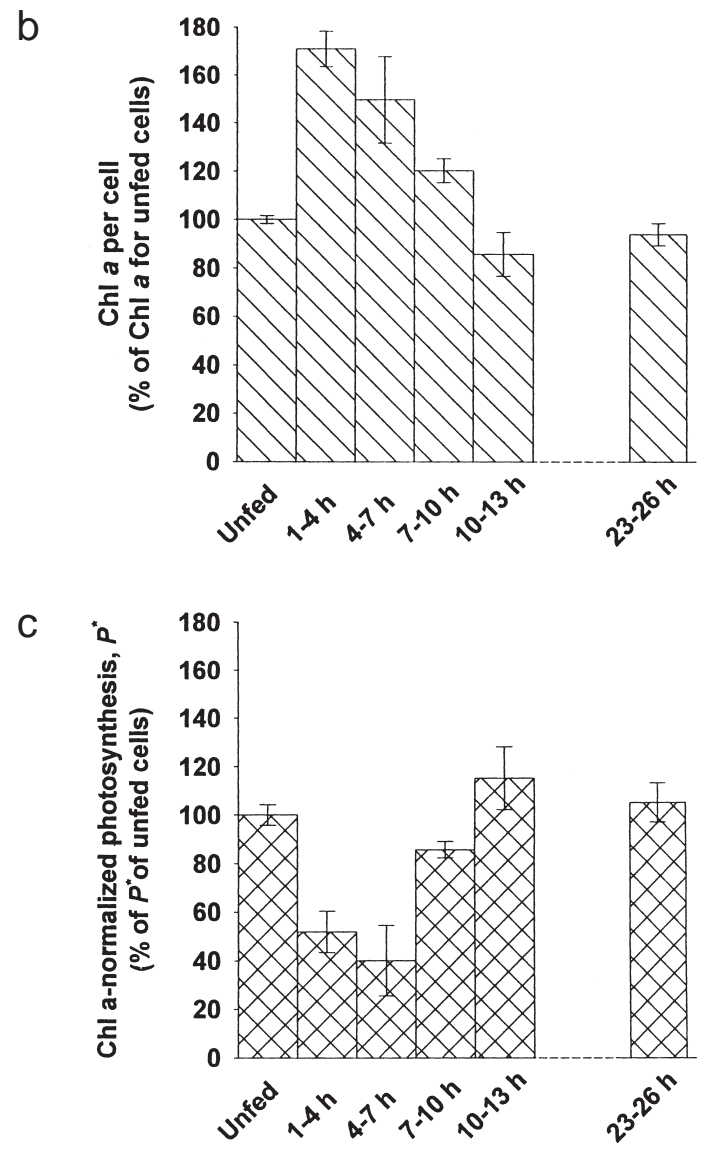

hours after feeding

Fig. 7. (a) Photosynthetic performance, (b) cellular chl a content, and (c) chl a-normalized photosynthesis in Fragilidium subglobosum cells that have been fed a single Ceratium tripos cell at the beginning of the experiment. All F. subglobosum cells were allowed to feed for $30 \mathrm{~min}$, after which they were separated from their prey. The time intervals given on the $x$-axis therefore refer to the incubation intervals (photosynthesis) after the initial mixture of F. subglobosum and the prey. Cells extracted for chl a are picked in the middle of these time intervals 
had a respiration rate of $123 \mathrm{pmol} \mathrm{O}_{2}$ cell $^{-1} \mathrm{~d}^{-1}$. Assuming a respiratory coefficient of 1 , this is equivalent to 840 and $1464 \mathrm{pg} \mathrm{C}$ cell $^{-1} \mathrm{~d}^{-1}$ for F. subglobosum grown in monocultures and mixotrophic cultures, respectively (Table 4).

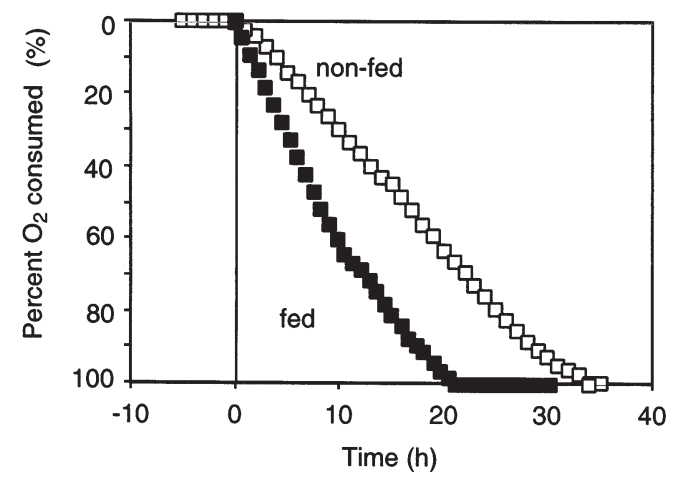

Fig. 8. Respiration experiments. Percentage of $\mathrm{O}_{2}$ consumed as a function of time in 400 Fragilidium subglobosum cells that have been grown as phototrophic and mixotrophic cultures prior to the experiment. Respiration rates were calculated using data from the first $3 \mathrm{~h}$ of the experiment

Table 3. Respiration rates of Fragilidium subglobosum cells grown in monoculture and mixotrophic cultures fed Ceratium tripos prior to the experiment. Numbers refer to treatment means $\pm 1 \mathrm{SE}, \mathrm{n}=$ number of replicates

\begin{tabular}{|lc|}
\hline Treatment & $\begin{array}{c}\text { Respiration rate } \\
\left(\mathrm{pmol} \mathrm{O}_{2} \text { cell }^{-1} \mathrm{~d}^{-1}\right)\end{array}$ \\
\hline Phototrophic cultures & $70.0 \pm 2.7(\mathrm{n}=4)$ \\
Mixotrophic cultures & $122.8 \pm 13.2(\mathrm{n}=4)$ \\
\hline
\end{tabular}

Table 4. Estimated daily gross C budget for Fragilidium subglobosum in mixotrophic cultures (fed Ceratium lineatum or C. tripos) at an irradiance of $50 \mu \mathrm{E} \mathrm{m} \mathrm{m}^{-2} \mathrm{~s}^{-1}$. Data on photosynthesis and growth rate are extracted from the transition experiments

\begin{tabular}{|c|c|c|c|c|}
\hline \multirow[t]{2}{*}{ Treatment } & \multicolumn{2}{|c|}{$\begin{array}{l}\text { Carbon uptake } \\
\left(\text { pg C cell }{ }^{-1} \mathrm{~d}^{-1}\right)\end{array}$} & \multicolumn{2}{|c|}{$\begin{array}{l}\text { Carbon spend } \\
\left(\text { pg C cell }{ }^{-1} \mathrm{~d}^{-1}\right)\end{array}$} \\
\hline & Photosynthesis & Ingestion & Growth & Respiration \\
\hline $\begin{array}{l}\text { Phototrophic } \\
\text { cultures }\end{array}$ & $2062^{\mathrm{a}}$ & 0 & $1000^{c}$ & $840^{\mathrm{d}}$ \\
\hline $\begin{array}{l}\text { Mixotrophic } \\
\text { cultures }\end{array}$ & $869^{\mathrm{a}}$ & $7380^{\mathrm{b}}$ & 3842 & $1464^{\mathrm{d}}$ \\
\hline \multicolumn{5}{|c|}{ 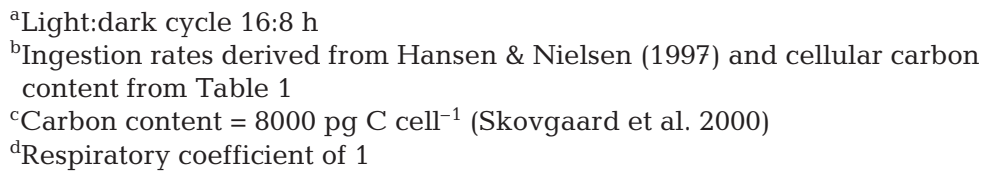 } \\
\hline
\end{tabular}

\section{DISCUSSION}

\section{How is the photosynthetic apparatus regulated in Fragilidium subglobosum and in other mixotrophic phytoflagellates?}

In the present experiments, Fragilidium subglobosum reduced its cellular chl a content by an average of $53 \%$ when offered food in excess at an irradiance of $50 \mu \mathrm{E} \mathrm{m} \mathrm{m}^{-2} \mathrm{~s}^{-1}$. Two possible mechanisms can be suggested to account for this reduction: (1) chl $a$ is diluted through an increase in growth rate leaving the net production of chl a $\left(\right.$ cell $^{-1} \mathrm{~d}^{-1}$ ) unaffected, or (2) chl a production is repressed by organic molecules from the digestion process.

The net production of chl a can roughly be estimated by multiplying the average growth rate and the average cellular chl a content (Table 1). In the present study the chl a production in a phototrophic Fragilidium subglobosum cell could be estimated as $20.9 \pm$ $3.5 \mathrm{pg}$ chl $a \mathrm{~d}^{-1}$ (average $\pm 1 \mathrm{SE}$ ), while that of the mixotrophic $F$. subglobosum was $32.0 \pm 3.2 \mathrm{pg} \mathrm{chl} \mathrm{a} \mathrm{d} \mathrm{d}^{-1}$ (average $\pm 1 \mathrm{SE}$ ). However, this calculation does not take into account that a part of the chl $a$ in the mixotrophic F. subglobosum cell is obtained through the ingestion of food.

The contribution of the ingested chl a can be estimated using the following data: (1) Fragilidium subglobosum ingests a single Ceratium tripos every $40 \mathrm{~h}$ (Hansen \& Nielsen 1997; (2) C. tripos contains 111 pg chl a cell ${ }^{-1}$ (Table 2); (3) ingested chl $a$ is degraded at a rate of $\sim 10 \mathrm{pg} \mathrm{chl} \mathrm{a} \mathrm{h} \mathrm{h}^{-1}$ (extracted from data shown in Fig. 7). The integration of these data over a $40 \mathrm{~h}$ period indicates that on average $16.5 \mathrm{pg} \mathrm{chl} \mathrm{a} \mathrm{cell}{ }^{-1}$ is derived from ingested food. Thus, the true chl a net production by $F$. subglobosum can be estimated as $25 \mathrm{pg}$ chl a d $\mathrm{d}^{-1}$ ([78 to 16.5$] \mathrm{pg}$ chl $a \times 0.41 \mathrm{~d}^{-1}$ ), which is not significantly different from that found in purely photosynthetic F. subglobosum. These considerations indicate that the chl a net production $\left(\mathrm{cell}^{-1}\right)$ in F. subglobosum is not affected by food uptake and that the photosynthetic apparatus and phagotrophic apparatus at this irradiance appear to be to completely separate systems.

Studies on the effect of feeding on chl a content and growth rate in mixotrophs are generally lacking. An exception is the study by Sanders et al. (1990) on the chrysophyte Poterioochromonas malhamensis. In transition experiments from phototrophy to mixotrophy this species reduces its chl a 
cell content by as much as 93 to $96 \%$. The growth rate of $P$. malhamensis grown phototrophically without food was $<0.1 \mathrm{~d}^{-1}$ at an irradiance of $200 \mu \mathrm{E} \mathrm{m} \mathrm{m}^{-2} \mathrm{~s}^{-1}$. When fed bacteria, the growth rate of $P$. malhamensis increased to $2.2 \mathrm{~d}^{-1}$. Thus, these data suggest that the large decrease in chl a content found in P. malhamensis when fed is due to the increased growth rate, just like in Fragilidium subglobosum. Future studies will tell whether this is a general phenomenon or not.

\section{Recycling of carbon}

Photosynthesis in the present experiments was measured using the incorporation of ${ }^{14} \mathrm{C}$ labeled $\mathrm{HCO}_{3}{ }^{-}$. The application of this technique for studying photosynthesis in mixotrophs is potentially problematic, because respiration of carbon acquired through phagotrophy will release inorganic carbon, which can then become recycled within the cell. This will result in isotope dilution inside the mixotroph, leading to an underestimate of the actual photosynthetic rate. The situation is further complicated in a mixotroph like Fragilidium subglobosum, because the food also contains chl a. To what extent the chlorophyll from the ingested prey is active is unknown.

An experiment in which Fragilidium subglobosum was fed a single Ceratium tripos cell (Fig. 7.) demonstrated a reduction in photosynthetic performance within the first $8 \mathrm{~h}$ (Fig. 7). From this experiment the underestimation of the photosynthetic performance can be estimated using the following data and assuming that the ingestion of prey is taking place in the beginning of the light period: (1) F. subglobosum ingests 1 single $C$. tripos per generation (Hansen \& Nielsen 1997); (2) generation time of mixotrophic $F$. subglobosum $=40 \mathrm{~h}_{\text {; }}$ (3) a light:dark cycle of 16:8 h. Thus integrating the ${ }^{14} \mathrm{C}$ incorporation rates shown in Fig. 7 over $40 \mathrm{~h}$ suggests that the underestimation of photosynthetic performance would be around 5 to $12 \%$, depending on whether the reduction is expressed as in terms of cell ${ }^{-1}$ or $\mathrm{chl} a^{-1}$, respectively.

\section{Carbon budget}

The relative importance of phagotrophy and photosynthesis for the daily uptake of carbon for Fragilidium subglobosum in mixotrophic culture at different irradiances was considered in Skovgaard et al. (2000). The data presented in the present paper allow a calculation of the fate of the carbon uptake at an irradiance of $50 \mu \mathrm{E} \mathrm{m} \mathrm{m}^{-2} \mathrm{~s}^{-1}$. Average values of the carbon uptake from photosynthesis and phagotrophy and the amount of carbon spent for growth and respiration by F. sub- globosum are all compiled in Table 4. In phototrophic F. subglobosum cells $\sim 48 \%$ of the daily assimilated carbon is used for growth, and $\sim 41 \%$ for respiration, leaving $\sim 11 \%$ for excretion. The same calculation for mixotrophic F. subglobosum cells indicates that $\sim 46 \%$ of the daily carbon uptake is used for growth, and $\sim 18 \%$ for respiration, leaving $\sim 36 \%$ for egestion and excretion. Thus, the assimilation efficiency in phototrophic F. subglobosum cells (89\%) is higher compared to mixotrophic F. subglobosum cells (64\%). A comparison of the fate of the assimilated carbon reveals that a significantly larger fraction of the assimilated carbon in phototrophic cells $(46 \%)$ is used for respiration as compared to that of mixotrophic cells $(28 \%)$. This is in accordance with Raven (1997) and others, who have suggested that the costs of running the photosynthetic apparatus in phototrophs and taking up inorganic nutrients are larger than those required to ingest and digest food.

Carbon budgets are not yet available for other mixotrophic dinoflagellates, making it impossible to say how important food uptake is for the metabolism of phototrophic dinoflagellates in general. However, Fragilidium subglobosum is not unique in its phagotrophic abilities. Recently, phagotrophy has been shown to be important for the growth of the phototrophic dinoflagellates F. cf. mexicanum and Gymnodinium galatheanum (Jeong et al. 1999, Li et al. 1999). It is, however, important to keep in mind that phagotrophy may play other roles in other phototrophic dinoflagellates. Some dinoflagellates, for instance (e.g. Heterocapsa triquetra, Prorocentrum minimum), only ingest prey when inorganic nutrients are limiting growth (Stoecker et al. 1997, Legrand 1998). Thus, during the past few years we have gained some knowledge on the possible roles of phagotrophy in phototrophic dinoflagellates from field and laboratory studies. However, the importance of phagotrophy for field populations of phototrophic dinoflagellates remains to be studied and will be a major task for future research.

Acknowledgements. We thank Michael Axelsen for technical help during the study. This work was funded by the Danish Natural Research Council project no. 9801391 to P.J.H. and no. 9701839-28808 to R.N.G. A.S. was supported by a PhD grant from The University of Copenhagen.

\section{LITERATURE CITED}

Bockstahler KR, Coats DW (1993) Spatial and temporal aspects of mixotrophy in Chesapeake Bay dinoflagellates. J Eukaryot Microbiol 40:49-60

Glud RN, Gundersen JK, Ramsing NB (in press) Oxygen sensors for in situ use: electrochemical and optical microsensors and 2D sensors. In: Buttle J, Harvai G (eds) In situ 
monitoring of aquatic systems: chemical analysis and speciation. John Wiley and Sons, Ltd., Chichester

Green JC (1990) Phagotrophy in prymnesiophyte flagellates. In: Patterson DJ, Larsen J (eds) The biology of free-living heterotrophic flagellates. Clarendon Press, Oxford, p 401-414

Hansen PJ (1989) The red tide dinoflagellate Alexandrium tamarense: effects on behaviour and growth of a tintinnid ciliate. Mar Ecol Prog Ser 53:105-116

Hansen PJ (1998) Phagotrophic mechanisms and prey selection in mixotrophic phytoflagellates. In: Anderson DM, Cembella AD, Hallegraeff GM (eds) Physiological ecology of harmful algal blooms. Springer Verlag, Jena, p 525-537

Hansen PJ, Nielsen TG (1997) Mixotrophic feeding of Fragilidium subglobosum (Dinophyceae) on three species of Ceratium: effects of prey concentration, prey species and light intensity. Mar Ecol Prog Ser 147:187-196

Jeong HJ, Shim JH, Kim JS, Park JY, Lee CW, Lee Y (1999) Feeding by the mixotrophic thecate dinoflagellate Fragilidium cf. mexicanum on red-tide and toxic dinoflagellates. Mar Ecol Prog Ser 176:263-277

Jones HLJ, Durjun P, Leadbeater BSC, Green JC (1995) The relationship between photoacclimation and phagotrophy with respect to chlorophyll $a$, carbon and nitrogen content, and cell size of Chrysochromulina brevifilum (Prymnesiophyceae). Phycologia 34:128-134

Jones RI (1994) Mixotrophy in planktonic protists as a spectrum of nutritional strategies. Mar Microb Food Webs 8:87-96

Legrand C, Granéli E, Carlsson P (1998) Induced phagotrophy in the photosynthetic dinoflagellate Heterocapsa triquetra. Aquat Microb Ecol 15:65-75

Editorial responsibility: John Austin (Assistant Editor), Oldendorf/Luhe, Germany
Li A, Stoecker DK, Adolf JE (1999) Feeding, pigmentation, photosynthesis and growth of the mixotrophic dinoflagellate Gyrodinium galatheanum. Aquat Microb Ecol 19: 163-176

Porter KG (1988) Phagotrophic phytoflagellates in microbial food webs. Hydrobiologia 159:89-97

Raven JA (1997) Phagotrophy in photoautotrophs. Limnol Oceanogr 42:198-205

Revsbech NP (1989) An oxygen microelectrode with a guard cathode. Limnol Oceanogr 34:474-478

Revsbech NP, Jørgensen BB (1986) Microelectrodes and their use in microbial ecology. In: Marshall KC (ed) Advances in microbial ecology, Vol 9. Plenum Press, New York, p 293-352

Sanders RW, Porter KG, Caron DA (1990) Relationships between phototrophy and phagotrophy in the mixotrophic chrysophyte Poterioochromonas malhamensis. Microb Ecol 19:97-109

Skovgaard A (1996) Mixotrophy in Fragilidium subglobosum (Dinophyceae): growth and grazing responses as functions of light intensity. Mar Ecol Prog Ser 143:247-253

Skovgaard A, Hansen PJ, Stoecker DK (2000) Physiology of the mixotrophic dinoflagellate Fragilidium subglobosum. I. Effects of phagotrophy and irradiance on photosynthesis and carbon content. Mar Ecol Prog Ser 201:129-136

Stoecker DK (1999) Mixotrophy among dinoflagellates. J Eukaryot Microbiol 46:397-401

Stoecker DK, Li A, Coats DW, Gustafson DE, Nannen MK (1997) Mixotrophy in the dinoflagellate, Prorocentrum minimum. Mar Ecol Prog Ser 152:1-12

Submitted: June 24, 1999; Accepted: February 8, 2000

Proofs received from author(s): June 29, 2000 